\title{
Adequacy of Food Aid Packs Provided during Natural Disasters: A Provincial Case Study
}

\author{
Katrina G. Gomez and Ma. Socorro E. Ignacio \\ Department of Nutrition, College of Public Health, University of the Philippines Manila
}

\begin{abstract}
Background. Due to the devolved nature of Philippine local governance, disaster management systems such as relief work and food aid pipelines, have been managed by local government units during natural disasters.

Objectives. This study assessed the nutrient adequacy of food aid packs provided during natural disasters in the province of Albay. Specific objectives included assessment of the types of food and food sources, as well as the practices in the food aid pipeline, and assessment of the nutritional quality of food aid packs through comparison with the recommended energy/nutrient intake (REI/RNI) for Filipinos.

Methods. Key informant interviews were conducted to gather information on food sources and pipelines. Information on the quantities of food components in food aid packs distributed was also collected, and the free iFRNI software used to derive nutrient content. These quantities compared with the REI/RNI for the general population. Descriptive statistics on Microsoft Excel were used to calculate the mean, median and mode for macronutrients as well as Vitamin A and iron to determine the overall intake of individuals relying on these foods. Ethical clearance was secured from the University of the Philippines REB.
\end{abstract}

Results. Analysis of the food components showed that the food aid packs were insufficient to meet the REI/ $\mathrm{RNI}$ for the general population, particularly for food packs distributed on the barangay and city/municipal levels. Food was sourced from local suppliers as an emergency purchase during the forecast of a disaster, in place of the prescribed practice of stockpiling. Procured food would then be repacked and distributed on the provincial, city/ municipal and barangay levels in a staggered schedule depending upon the length of the disaster or evacuation.

Conclusion. The food packs distributed by the barangay and city/municipal sub-units of the provincial government of Albay are insufficient to meet the daily caloric and micronutrient needs of a general population purely reliant on food aid after a natural disaster.

Key Words: natural disasters, nutrition, food aid

\section{INTRODUCTION}

The Philippines has been known to be vulnerable to various natural calamities, which resulted in the internal displacement of affected populations and the disruption of the availability of essential goods and services. These natural disasters have included typhoons and tropical storms, as well as earthquakes and volcanic eruptions. It was estimated by

Paper presented as poster at the $2^{\text {nd }}$ AUN International Health Promotion Conference, Aug 20-21, 2019, Novotel Manila.

Corresponding author: Katrina G. Gomez, MD, MPH Department of Nutrition

College of Public Health

University of the Philippines Manila

625 Pedro Gil St. Ermita, Manila

1000 Philippines

Email: kggomez@up.edu.ph the Philippine Atmospheric, Geophysical, and Astronomical Services Administration that about 20 typhoons entered the Philippine Area of Responsibility each year, with about 5 causing major damage. ${ }^{1}$ Several active faults and 24 active volcanoes have also been documented by the Philippine Institute for Volcanology and Seismology. ${ }^{2}$ Due to the Philippine's vulnerability to natural calamities, it has become necessary for the government on both national and 
local levels to design programs for disaster risk reduction and management.

Due to the devolution of government powers and services, the actual conduct of relief operations such as evacuation and food aid has been put under the purview of the local government units. Non-government organizations have augmented relief operations in different capacities. Factors such as availability and cost of food supplies have affected the selection, quantity, and quality of food distributed in relief efforts, and consequently, their nutritional value for the affected communities. It has been deemed essential to assess the responsiveness of the food aid system and the nutritional value of such food aid, in the interest of prevention of acute malnutrition in the internally displaced population.

This study aimed to assess the food aid system of Albay Province, mainly about the macronutrient and micronutrient content provided by food aid packs compared with the Recommended Energy Intake/Recommended Nutrient Intake (REI/RNI) in the Philippine Dietary Reference Intakes for different age groups in the Filipino population. This case study was limited to assessing adequacy of food aid for the general population. It did not include food aid or specialized interventions targeted towards vulnerable populations such as pregnant and lactating mothers or children assessed with moderate or severe acute malnutrition.

\section{MATERIALS AND METHODS}

This case study utilized key informant interviews, corroborated by a review of records such as logbooks and datasheets for tracking and receipt of donations, to gather data on the food aid system of the province during times of natural calamities. Convenience, non-purposive sampling was used to select the province of Albay and key informants in the LGU system and other organizations. The following criteria were used for selection of the province for this study:

- The province has been known to be vulnerable to two types of natural calamities, namely typhoons and seismic calamities such as volcanic eruptions and earthquakes, and has developed programs to address both types of disaster.

- The LGU of Albay has responded to several natural disasters such as the Mayon Volcano eruption of 2018, and tropical depression Usman in 2019.

- Consent was obtained from the province's Governor, coursed through the Albay Public Safety and Emergency Management Office

Point persons for this key informant interview included:

- Provincial/City/Municipal Health Officer

- Provincial/City/Municipal Social Worker

- Implementors in the community (barangay captains, kagawads)

- NGO representatives from local office/branches
Inclusion criteria were as follows: the key informant interview participant should have been involved in local disaster response efforts within five years before this study, should have been part of the organizational structure of agency or group involved with the food pipeline in disaster response, or a member of agency or office involved in nutritional assessment and planning for nutritional needs of the community. Exclusion criteria were as follows: respondent was not in a position to discuss past and present disaster response measures for locality due to administrative constraints or insufficient knowledge of past and current practices, respondent was currently under investigation/ preventive suspension for administrative complaints, and respondent refused to participate voluntarily or declined to be interviewed.

The key informant interview covered the following areas: sources of food, dates of stockpiling, places of storage, transportation, receipt, and distribution of each food component, and tracking practices implemented throughout previous disasters. Information on previously distributed food aid packages was also collected in the interview. The interview schedule was based on the checklist for supply chain management provided by the Sphere Project. The Sphere Project provides a guideline for minimum standards for humanitarian aid. These standards cover different interventions such as food aid, housing, and sanitation. About food aid, the Sphere Project details a minimum caloric requirement of 2,100 kcal per person, as well as practices for logistics, transportation, and distribution of aid in affected areas. ${ }^{3}$ Classification of components of food rations was derived from the WHO Guidelines for Food and Nutrition Needs in Emergencies. ${ }^{4} \mathrm{~A}$ checklist of documents for review was also prepared based on the same checklist from the Sphere Project. Each interview was conducted within one and a half hours.

The interviews were then transcribed and analyzed for common themes relating to practices in the food pipeline as well as sourcing of food. Information on quantities of food distributed was used as the basis for calculation for the nutrient content of each food pack, assuming equal distribution in a household. No data was gathered concerning in-home use of food rations. Descriptive statistics on Microsoft Excel were used to calculate the mean, median, and mode for macronutrients as well as Vitamin A and iron. The iFNRI software was used to derive the values for nutrient content, which were then compared with the RNI/ REI in the Philippine Dietary Reference Intakes ${ }^{5}$ for the following age groups: adults aged 19-29 years old, 30-49 years old, and 50-59 years old, as well as children in the following age groups: 6-11 months, 3-5 years old, and 10-12 years old. The calculation for macronutrients as well as Vitamin A and iron was done assuming equal intake regardless of age.

The following were assessed for adequacy by comparison with the different REI/RNI values for the general population: daily intake of kilocalories from $100 \%$ reliance 
on food pack, and daily intake of the micronutrients iron and Vitamin A.

Before data gathering, ethical clearance was obtained from the University of the Philippines Research Ethics Board. Letters of introduction were given to heads of departments and local executives asking for permission to conduct data gathering in their respective offices. Informants were given informed consent forms in English and Filipino. Identifying information of each informant was anonymized for further data protection.

\section{RESULTS}

A total of 7 respondents were interviewed for this case study. The following agencies were represented:

1. Albay Province's Disaster Risk Reduction (DRR) office

2. Albay Province's Social Welfare Department

3. Albay Province's Provincial Health Office

4. Legazpi City's Social Welfare Department

5. Barangay Oro Site, Legazpi City, Albay

6. Philippine Red Cross, Legazpi Albay Chapter

All these agencies and their counterparts in other areas of Albay Province coordinated with one another upon a forecast of a natural disaster. Baseline nutritional assessment of the population was done by the health sector, who coordinated with other agencies to finalize the target list of households to receive food aid. The main LGU actor for the food pipeline in the province of Albay was the Provincial Social Welfare Department Office (PSWDO). This office had counterparts in the provincial and city/municipal levels, namely the Provincial Social Welfare Department (PSWD) and City/Municipal Social Welfare Department (CSWD or MSWD). The CSWD or MSWD coordinated closely with all barangays to facilitate the distribution of food aid to the targeted households. Barangays, particularly their captains and members of the barangay council tasked to chair disaster risk reduction and management initiatives, were in charge of prepositioning food packs in evacuation centers. Thus, food would be delivered in a staggered fashion, with the barangay as the first line of food aid, followed by the CSWD or MSWD, then the PSWD. The relationship between different actors in this food pipeline is illustrated in Figure 1.

The LGU procured the bulk of its food from local suppliers and agencies such as the National Food Authority as well as accredited stores and retailers. Memoranda of Agreement were prepared by the General Services office on the provincial level, or by the local chief executives on other levels of the LGU. No issues were reported with the budget or financing. Food procured by the LGU was augmented by donations from the private sector and national government offices such as the Office of the President. The standard composition of food packs distributed by different levels of the LGU has been detailed in Table 1.

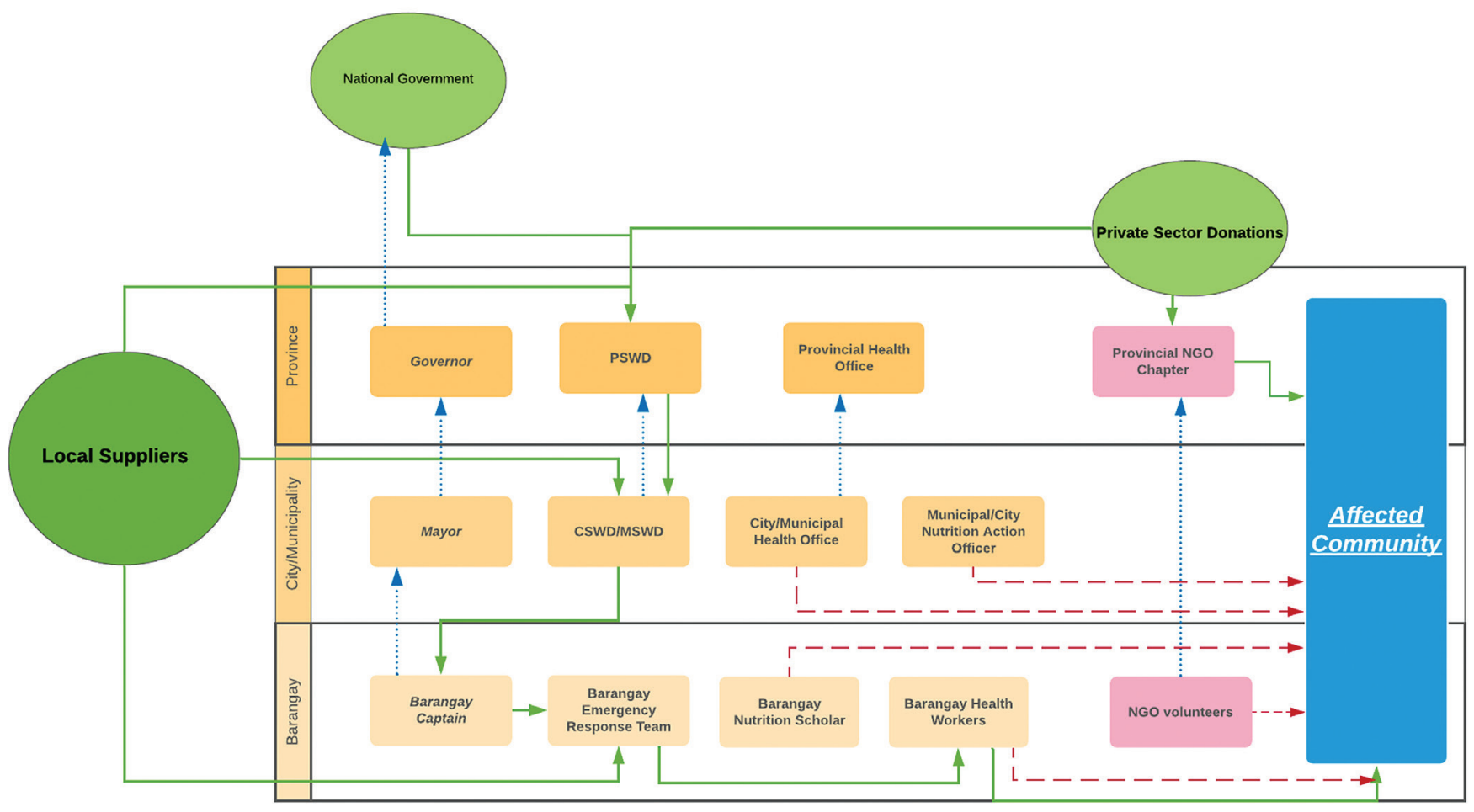

Legend: Green Circles: Sources of food aid; Green arrows: Flow of food; Maroon broken arrows: Flow of assessment; Blue dotted arrows: Vertical communication between agencies.

Figure 1. Food Pipeline of Albay Province. 
Adequacy of Food Aid Packs Provided during Natural Disasters

Table 1. Composition of Food Packs Provided by Different Levels of the Albay LGU

\begin{tabular}{lcccccc}
\multicolumn{1}{c}{ Food Component } & $\begin{array}{c}\text { PSWD package } \\
\text { (in kg) }\end{array}$ & $\begin{array}{c}\text { Serving size } \\
\text { (in kg) }\end{array}$ & $\begin{array}{c}\text { CSWD package } \\
\text { (in kg) }\end{array}$ & $\begin{array}{c}\text { Serving size } \\
\text { (in kg) }\end{array}$ & $\begin{array}{c}\text { Barangay Oro } \\
\text { Site (in kg) }\end{array}$ & $\begin{array}{c}\text { Serving Size } \\
\text { (in kg) }\end{array}$ \\
Rice & 3 & 0.16 & 3 & 0.16 & 3 & 0.16 \\
Instant Noodles & 2.4 & 0.13 & 0.3 & 0.17 & 0.2 & 0.011 \\
Canned sardines & 4.8 & 0.27 & 0.6 & 0.33 & 0.4 & 0.022 \\
Corned beef & 4.8 & 0.27 & 0.6 & 0.033 & 0.4 & NA \\
Instant coffee 3 in 1 & 0.540 & 0.009 & 0.54 & 0.009 & NA & NA \\
Chicken egg & 0.057 & 0.057 & NA & NA & NA \\
Fish & 1.0 & 0.17 & NA & NA & NA \\
Dressed chicken & 1.0 & 0.17 & NA & NA & NA \\
Canned milk & 1.0 & 0.33 & NA & NA \\
\hline
\end{tabular}

Legend: PSWD: Provincial Social Welfare Department; CSWD: City Social Welfare Department.

Non-government organizations functioned as auxiliary or service augmentation. These included the Philippine Red Cross, Rotary Club, and other civic organizations, which were tapped to augment food aid from the LGU. The NGOs used no standard composition for food packs. The only criterion used for nutritional adequacy was that stipulated in the Sphere guidelines for humanitarian aid. Collectively, food aid from these NGOs targeted $30 \%$ or less of the affected population.

Food packs distributed by the PSWD were designed for a household of 6 persons, to last up to 3 days. Milk was only provided to households with children from 6 months of age to school age. Fresh food such as dressed chicken or fish was distributed only to add variety to the diet and augment nutrient adequacy during prolonged stays in evacuation centers. Food packs distributed by the CSWD of Legazpi were also expected to last a household for 3 days, regardless of household size or composition. This was true also for food packs prepositioned by Barangay Oro Site. For uniformity, the household size of 6 persons was used to calculate for the energy intake, as well as iron and Vitamin A intakes from each food pack. Infants and from the age of 6 to 11 months, as well as young children from 3 to 5 years old were also considered to have equal food intake with adults 19-29 years old, 30-49 years old, and 50-59 years old, as well as children from 10 to 12 years old. Food packs from the LGUs were limited strictly to dry goods for cooking in evacuation centers. These did not include ready to eat meals as well as other interventions such as micronutrient supplementation, ready to use therapeutic foods to help address moderate and severe acute malnutrition. The energy provision and specified micronutrient contents were compared with the REI/RNI for different age groups and sexes, as detailed in Table 2.

Table 2 summarized the adequacy of food aid packs provided by different levels of the LGU in terms of percentage of REI/RNI provided for different age groups. The food aid packs distributed by the PSWD provided adequate energy for all age groups and met the RNI values for Vitamin A and iron intakes for young children. Vitamin A and iron were included in the assessment due to the presence of fortification and supplementation measures in the existing health services, as well as their importance about the prevention of micronutrient deficiencies. It was found that a food pack given to a household relying solely on LGU food aid would be inadequate to meet the RNI for micronutrient intake for older children (adolescents aged 10-12 years old as well as adults. Food aid packs from both the CSWD and barangay provided less than $50 \%$ for energy for adults and children 10 12 years old, and also fell below 25\% for the vitamin A and iron recommendations for all age groups. The prepositioned packs from the barangays were the least adequate in terms of both energy and vitamin A and iron provision.

\section{DISCUSSION}

The disaster management and risk reduction system in the province of Albay, covering both the LGU and partner NGOs were patterned after the specifications stipulated in the Sphere recommendations and minimum standards for humanitarian aid, as well as national legislation such as the Department of Social Welfare, Administrative Order 51 Series of 2003, which has guided the conduct of food aid operations from stockpiling to distribution. ${ }^{6}$ Two exemplary features of Albay's disaster management system were preemptive assisted evacuations and coordination among different partners from the time a disaster forecast was made. The result of such coordination was a list of target households who would receive various sorts of aid, both food and nonfood, from the LGU and its partners.

Although there are recommendations as to the nutrient values of food aid to the displaced population, the exact composition of food aid components remains unclear since this may vary according to the following factors:

- The phase of disaster relief; during the initial phase in the immediate aftermath of a disaster, food aid is provided according to baseline or pre-disaster assessment of the population. In the second phase of disaster, when the subsequent nutritional assessment has been conducted, food aid is tailored to the current nutritional status of the population, with special attention given to vulnerable groups such as undernourished children and pregnant or lactating mothers.

- Staples must be familiar to and accepted to the population. $^{7}$ 
Table 2. Summary of the adequacy of food aid provided by Albay LGU in terms of REI/RNI for different age groups

\begin{tabular}{|c|c|c|c|}
\hline & $\begin{array}{l}\text { PSWD relief pack } \\
\text { W/o milk: } 2722 \text { kcal } \\
494 \text { ug RE Vit A } \\
10.1 \text { mg Iron } \\
\text { W/milk: } 2,806 \mathrm{kcal} \\
624 \text { ug RE Vit A } \\
11.4 \mathrm{mg} \text { Iron }\end{array}$ & $\begin{array}{l}\text { CSWD relief pack } \\
810 \mathrm{kcal} \\
8 \mathrm{ug} \text { RE Vit A } \\
2 \mathrm{mg} \text { Iron }\end{array}$ & $\begin{array}{l}\text { Barangay relief pack } \\
714 \mathrm{kcal} \\
5 \mathrm{ug} \text { RE Vit A } \\
1.9 \mathrm{mg} \text { Iron }\end{array}$ \\
\hline $\begin{array}{l}\text { Total calories for adults } 19-29 \text { years } \\
\text { Males: } 2,530 \mathrm{kcal} \\
\text { Females: } 1,930 \mathrm{kcal}\end{array}$ & $\begin{array}{l}107.6 \% \text { (males) } \\
141.0 \% \text { (females) }\end{array}$ & $\begin{array}{l}32.0 \% \text { (males) } \\
50.0 \% \text { (females) }\end{array}$ & $\begin{array}{l}28.2 \% \text { (males) } \\
37.0 \% \text { (females) }\end{array}$ \\
\hline $\begin{array}{l}\text { Total calories for adults } 30-59 \text { years } \\
\text { Males: } 2,420 \mathrm{kcal} \\
\text { Females: } 1,870 \mathrm{kcal} \\
\end{array}$ & $\begin{array}{l}112.5 \% \text { (males) } \\
145.6 \% \text { (females) }\end{array}$ & $\begin{array}{l}33.5 \% \text { (males) } \\
43.3 \% \text { (females) }\end{array}$ & $\begin{array}{l}29.5 \% \text { (males) } \\
38.2 \% \text { (females) }\end{array}$ \\
\hline $\begin{array}{l}\text { Recommended Vit } A \text { for adults } 19-59 \text { years } \\
\text { Males: } 700 \text { ug RE } \\
\text { Females: } 600 \text { ug RE }\end{array}$ & $\begin{array}{l}70.6 \% \text { (males) } \\
82.3 \% \text { (females) }\end{array}$ & $\begin{array}{l}1.1 \% \text { (males) } \\
1.3 \% \text { (females) }\end{array}$ & $\begin{array}{l}0.7 \% \text { (males) } \\
0.8 \% \text { (females) }\end{array}$ \\
\hline $\begin{array}{l}\text { Recommended Iron for adults } 19-49 \text { years } \\
\text { Males: } 12 \mathrm{mg} \\
\text { Females: } 28 \mathrm{mg} \\
\end{array}$ & $\begin{array}{l}\text { 84.2\% (males) } \\
36.1 \% \text { (females) }\end{array}$ & $\begin{array}{l}\text { 16.7\% (males) } \\
7.14 \% \text { (females) }\end{array}$ & $\begin{array}{l}15.8 \% \text { (males) } \\
6.8 \% \text { (females) }\end{array}$ \\
\hline $\begin{array}{l}\text { Recommended Iron for adults } \mathbf{5 0 - 5 9} \text { years } \\
\text { Males: } 12 \mathrm{mg} \\
\text { Females: } 10 \mathrm{mg} \\
\end{array}$ & $\begin{array}{l}84.2 \% \text { (males) } \\
101 \% \text { (females) }\end{array}$ & $\begin{array}{l}16.7 \% \text { (males) } \\
20 \% \text { (females) }\end{array}$ & $\begin{array}{l}15.8 \% \text { (males) } \\
19 \% \text { (females) }\end{array}$ \\
\hline $\begin{array}{l}\text { Total calories for children } 6-11 \text { months } \\
\text { Males: } 720 \mathrm{kcal} \\
\text { Females: } 630 \mathrm{kcal}\end{array}$ & $\begin{array}{l}389.7 \% \text { (males) } \\
445.4 \% \text { (females) }\end{array}$ & $\begin{array}{l}112.5 \% \text { (males) } \\
128.6 \% \text { (females) }\end{array}$ & $\begin{array}{l}\text { 99.2\% (males) } \\
113.3 \% \text { (females) }\end{array}$ \\
\hline $\begin{array}{l}\text { Total calories for children } 3-5 \text { years } \\
\text { Males: } 1,350 \mathrm{kcal} \\
\text { Females: } 1,260 \mathrm{kcal} \\
\end{array}$ & $\begin{array}{l}207.9 \% \text { (males) } \\
222.7 \% \text { (females) }\end{array}$ & $\begin{array}{l}\text { 60.0\% (males) } \\
64.3 \% \text { (females) }\end{array}$ & $\begin{array}{l}52.9 \% \text { (males) } \\
56.7 \% \text { (females) }\end{array}$ \\
\hline $\begin{array}{l}\text { Total calories for children } 10-12 \text { years } \\
\text { Males: } 2,060 \mathrm{kcal} \\
\text { Females: } 1,980 \mathrm{kcal} \\
\end{array}$ & $\begin{array}{l}136.2 \% \text { (males) } \\
141.8 \% \text { (females) }\end{array}$ & $\begin{array}{l}39.3 \% \text { (males) } \\
40.9 \% \text { (females) }\end{array}$ & $\begin{array}{l}34.7 \% \text { (males) } \\
36.1 \% \text { (females) }\end{array}$ \\
\hline $\begin{array}{l}\text { Recommended Vit } \mathrm{A} \text { for children 6-11 months, } 3-5 \text { years } \\
\text { Males: } 400 \text { ug RE } \\
\text { Females: } 400 \text { ug RE }\end{array}$ & $\begin{array}{l}156.5 \% \text { (males) } \\
156.5 \% \text { (females) }\end{array}$ & $\begin{array}{l}2.0 \% \text { (males) } \\
2.0 \% \text { (females) }\end{array}$ & $\begin{array}{l}1.25 \% \text { (males) } \\
1.25 \% \text { (females) }\end{array}$ \\
\hline $\begin{array}{l}\text { Recommended Vit } \mathrm{A} \text { for children } 10-12 \text { years } \\
\text { Males: } 500 \text { ug RE } \\
\text { Females: } 500 \text { ug RE }\end{array}$ & $\begin{array}{l}124.8 \% \text { (males) } \\
124.8 \% \text { (females) }\end{array}$ & $\begin{array}{l}1.6 \% \text { (males) } \\
1.6 \% \text { (females) }\end{array}$ & $\begin{array}{l}1.0 \% \text { (males) } \\
1.0 \% \text { (females) }\end{array}$ \\
\hline $\begin{array}{l}\text { Recommended Iron for children 6-11 months } \\
\text { Males: } 10 \mathrm{mg} \\
\text { Females: } 9 \mathrm{mg}\end{array}$ & $\begin{array}{l}114.0 \% \text { (males) } \\
126.7 \% \text { (females) }\end{array}$ & $\begin{array}{l}20 \% \text { (males) } \\
22.2 \% \text { (females) }\end{array}$ & $\begin{array}{l}\text { 19\% (males) } \\
21.1 \% \text { (females) }\end{array}$ \\
\hline $\begin{array}{l}\text { Recommended Iron for children } 3-5 \text { years } \\
\text { Males: } 9 \mathrm{mg} \\
\text { Females: } 9 \mathrm{mg}\end{array}$ & $\begin{array}{l}\text { 126.7\% (males) } \\
126.7 \% \text { (females) }\end{array}$ & $\begin{array}{l}22.2 \% \text { (males) } \\
22.2 \% \text { (females) }\end{array}$ & $\begin{array}{l}21.1 \% \text { (males) } \\
21.1 \% \text { (females) }\end{array}$ \\
\hline $\begin{array}{l}\text { Recommended Iron for children } 10-12 \text { years } \\
\text { Males: } 12 \mathrm{mg} \\
\text { Females: } 20 \mathrm{mg}\end{array}$ & $\begin{array}{l}\text { 95.0\% (males) } \\
57.0 \% \text { (females) }\end{array}$ & $\begin{array}{l}16.7 \% \text { (males) } \\
10.0 \% \text { (females) }\end{array}$ & $\begin{array}{l}15.8 \% \text { (males) } \\
9.5 \% \text { (females) }\end{array}$ \\
\hline
\end{tabular}

Legend: PSWD: Provincial Social Welfare Department; CSWD: City Social Welfare Department; REI/RNI: Recommended Energy Intake/Recommended Nutrient Intake; RE: Retinol equivalents (for Vitamin A).

These considerations, combined with those already part of the Sphere recommendations, guide the planning of food aid interventions in times of disaster.

National guidelines for food aid have been uniform: the AO 51 enforced by the national office of DSWD stated that a food pack must be suitable for a 6-person household, and the provincial social welfare department followed this recommendation. However, the more updated national standards for disaster relief stipulated that family packs should be for five persons, to last for three days. ${ }^{8}$ Despite the presence of these guidelines, food packs uniformly comprised of rice, instant noodles, and canned goods were distributed by the city/municipal offices or prepositioned by the barangays regardless of the number of persons comprising each household. However, the actual number of individuals in each household, relying on food aid varied. As a result, large or multi-family households may have had less food consumed per person.

The types of foods distributed by these LGU subunits were mostly non-perishable dry goods such as rice, 
canned goods, instant noodles, instant coffee, and chocolate powder. Only the PSWDO distributed fresh foods. The paucity of distributed foods that were rich in micronutrients also contributed to a low intake of vitamin $\mathrm{A}$ and iron in the affected population. Many of these foods had high-fat content. Thus individuals who reliant on these foods easily exceeded the REI/RNI for fat. For children 6-11 months old, fat must provide $30-40 \%$ of energy, while for children 3 to18 years old as well as adults, only $15-30 \%$ of calories must come from fat.

Food packs from both the City of Legazpi and Barangay Oro Site were nutritionally inadequate for the "standard" 6-person household used for theoretical calculations at the provincial level, assuming equal distribution of food for each individual in the absence of data regarding in-home use. With such distribution, the calculated caloric content of these food packs fell below the calorie requirement, particularly for adults and older children. The resulting food intake for individuals entirely reliant on food aid would still result in energy deficiencies, even if individual intake of some macronutrients fell within or exceeded REI/RNI recommendations. The limited food intake also resulted in limited intake of Vitamin A and iron, falling below the REI/ RNI for these micronutrients. The RNI for Vitamin A varies from 400 ug RE for children aged 6 to 11 months of both sexes, up to 600 ug RE for adult females, and 700 ug RE for males. The RNI for iron varies from 9 to $10 \mathrm{mg}$ for children aged 6 to 11 months, up to $28 \mathrm{mg}$ for adolescent girls and women of childbearing age.

The assumption for the calculation of food rations was that food could be equally distributed among members of a household. However, within households, food distribution patterns may differ such that certain groups or individuals may get food first or receive a larger share of food. Thus, no guarantee once distributed that the food packs will be sufficient to provide each individual the recommended percentage of macronutrients and micronutrients. It was also important to note that at least in Barangay Oro Site, vulnerable populations such as pregnant women and malnourished children were prioritized in receipt of food aid, thus improving their chances of receiving adequate nutrients

It was also important to note that though the Sphere recommendations were readily used to plan food aid, the following matters needed to be considered:

- Food aid allocations may also be tailored to local standards such as the AO 51 of the DSWD

- Micronutrient deficiencies must be addressed.

These were among the considerations when planning for the acquisition of food aid packs and the timing of food aid ingress into communities. In most cases, the problem of limited intake of food was remedied by the staggered distribution of food aid and augmentation from NGOs and evacuees' stocks. This was important for residents receiving food packs that were not adequate to provide the caloric and micronutrient requirements for different age groups if they solely rely on this food aid. However, in scenarios wherein food aid could not be given on a staggered schedule and evacuees were not able to procure food on their own, communities had to rely on the food packs providing a narrow variety of foods for 2 to 3 days, or until the next release of food aid from the LGU. The impact of these nutrient inadequacies in food packs was graver in disasters that required longer periods of evacuation such as earthquakes and volcanic eruptions and needed to be mitigated by the social welfare department in cooperation with the local health offices.

About non-government organizations, the reliance on donations did not make it feasible to have a standard composition for food packs. Nevertheless, the Philippine Red Cross followed the Sphere standards for food aid and allocated received food to fit these minimum requirements. The REI/RNI was not used as a basis for the nutrient content of these packs. Donations were divided and allocated only to meet the Sphere standards for nutrition. Since this organization and other NGO partners were not mandated to cover the entirety of an affected population and served as an augmentation to government efforts, they had more leeway in picking target communities to receive food aid; frequently, they were tapped to assist in areas being underserved by the LGU. In this case, the presence of additional food from these organizations augmented the limited food stocks from the LGU and helped affected individuals meet the REI/ RNI recommendations. Nevertheless, in scenarios wherein affected communities were prone to nutrient deficiencies, NGOs had to coordinate with the LGU to mitigate this problem, as part of the LGU's disaster risk and reduction management system.

As of the time of writing, there were no plans to include other ready to eat foods in the LGU packs. This would render the food packs less usable in communities cut off from water and electricity. The LGU did not regularly use other modes of food aid, such as the provision of hot meals, community kitchens, or food vouchers. Although individual interventions such as the provision of ready to use therapeutic food have been shown to reduce pediatric mortality in affected populations, these do not form part of the standard aid packages given to the affected community and are reserved for use after subsequent assessment by the health workers. ${ }^{9}$

\section{CONCLUSION}

The adequacy of food packs distributed during disasters varied across the different levels of the LGU, with the rations from the provincial government being the most adequate in terms of PDRI recommendations for energy, vitamin A and iron for different age groups. Food packs from the city level in the City of Legazpi, as well as the barangay level, were not sufficient to meet the REI/RNI for vitamin A and iron for communities subsisting entirely on food aid. 
The Albay LGU has adapted measures both from international and national disaster management standpoints to come up with a food pipeline to rapidly serve communities that have successfully preemptively evacuated in times of disaster. Both dry goods and fresh foods were sourced both locally and from donations. From here, food would be repacked and distributed to targeted communities and households. The food pipeline operated across three levels: provincial, city/municipality, and barangay, to reach affected communities in a staggered fashion.

It is recommended that a standard composition for food packs be created for all levels of the LGU to include foods that adhere more strongly to the REI/RNI requirements for each age group, or with updated Sphere standards. Apart from dry goods, other components such as ready to eat foods may be considered as part of the food aid package, particularly in areas with limited access to resources for cooking and storage of foods.

\section{Acknowledgments}

To Cedric Daep PhD and Ms. Lynn Manila of the Albay Public Safety and Emergency Management Office, for being instrumental in coordinating the fieldwork and interviews for this study.

To the respondents from different offices and agencies in Albay Province, for providing the data needed for this paper.

\section{Statement of Authorship}

Primary author conducted data collection and analysis, co-author served as adviser and approved final study.

\section{Author Disclosure}

All authors declared no conflicts of interest.

\section{Funding Source}

This paper was self-funded by the primary author.

\section{REFERENCES}

1. De La Cruz, G, Typhoons in the Philippines and the 2016 polls [Internet]. 2016 [cited 2018 Nov]. Available from: https://www. rappler.com/move-ph/issues/disasters/126001-typhoons-enterphilippines-fast-facts.

2. Philippine Institute of Volcanology and Seismology, List of Active Volcanoes in the Philippines [Internet].2017 [cited 2018 Nov].Available from: http://www.phivolcs.dost.gov.ph/index.php?option=com_conten t\&view $=$ article\&id $=8235 \% 3$ Aactive-volcanoes\&catid $=55 \&$ Itemid $=86$

3. Sphere Project, Humanitarian Charter and Minimum Standards in Disaster Response [Internet]. 2014 [cited 2018 Nov]. Available from: http://www.ndma.gov.pk/Publications/ Humanitarian\%20Charter\%20and\%20Minimum\%20Standards\%20 in\%20Disaster\%20Response\%20the\%20Sphere\%20Project.pdf

4. World Health Organization, Food and Nutrition Needs in Emergencies [Internet]. 2004 [cited 2018 Nov]. Available from: http://www.who. int/nutrition/publications/emergencies/a83743/en/

5. Food and Nutrition Research Institute, PDRI Tables [Internet]. 2015 [cited 2018 Nov]. Available from: http://www.fnri.dost.gov. $\mathrm{ph} /$ images/sources/PDRI-Tables.pdf

6. Department of Social Welfare and Development, Administrative Order 51 Series of 2003: Omnibus Guidelines and Procedures on the Maintenance and Operation of the National Resource Operations Center (NROC) [Internet]. 2003 [cited 2018 Nov]. Available from: https://www.dswd.gov.ph/issuances/AOs/AO_2003-051.pdf

7. Pothiawala S. Food and shelter standards in humanitarian action. Turk J Emerg Med. 2015 Oct;15(Suppl 1):34-9.

8. National Disaster Risk Reduction and Management Council, Disaster Preparedness Minimum Standards [Internet]. 2015 [cited 2019 May]. Available from: https://ga.gov.ph/media/uploads/2/ Publications\%20PDF/Book/NDPP\%20Minimum\%20Standards\%20 Vol\%202.pdf.

9. Balhara KS, Silvestri DM, Winders WT, Selvam A, Kiviehan SM, Becker TK, et al. Impact of nutrition interventions on pediatric mortality and nutrition outcomes in humanitarian emergencies: A systematic review. Trop Med Int Health. 2017 Dec; 22(12):1464-92. 